\title{
Survey of Classification and Organization of Videorecordings
}

\author{
Barbara Bergman, Jessica Schomberg, and Dorie Kurtz
}

Libraries have long struggled with the question of how to best classify and enable access to videorecordings. While giving a presentation at a state library conference, the authors observed from comments during the question and answer portion of the presentation that the libraries represented in the audience use a variety of video classification and organization practices. To better understand how local practices and librarians' attitudes regarding the efficacy of these practices vary, we conducted a survey soliciting responses from librarians representing a broad array of library types.

Barbara J. Bergman (barbara.bergman @mnsu.edu) is Media Services Librarian at Minnesota State University Mankato. Jessica Schomberg (jessica .schomberg@nmsu.edu) is Media Cataloger/Assessment Coordinator at Minnesota State University Mankato. Dorie Kurtz (dorie.kurtz@avila.edu) is Cataloging and Acquisitions Librarian at Avila University.

Manuscript submitted July 6, 2015: returned to authors for revision September 10, 2015; revised manuscript submitted November 5, 2015; manuscript returned to authors for minor revisions February 1, 2016; revised manuscript submitted March 9, 2016; accepted March 14, 2016.
$\mathrm{C}$ lassification is the act of systematically grouping similar things together. Within this study, the term "classification" refers to assigning call numbers that reflect subject content and are intended to support logical browsing of physical or virtual locations. Libraries continue to debate the question of how to best classify and provide access to video materials. While giving a presentation on the topic of video collections at a state library conference, the authors learned that libraries are using a wider variety of video classification and organization practices than we anticipated. That raised questions for us. We wanted to know whether this variation was a regional phenomenon or a general practice. Additionally, we also wanted to know whether librarians generally believed that their local practices for classifying videos adequately helped patrons. Therefore we decided to survey catalogers, media librarians (media selectors who may also do media cataloging), and generalists interested in video classification. We chose the survey method because it is an inexpensive way to obtain a broad range of responses from a wide audience nationally and, possibly, internationally. The authors anticipated that this would help identify areas requiring additional research. Because our research questions stemmed from a discussion with a diverse group of librarians, we intentionally tried to obtain responses that reflected the diversity of the profession for library type (academic, public, etc.) and organizational role (cataloging, collection development, etc.).

An additional idea that we had is that catalogers are enculturated to follow standard cataloging practices to insure interoperability between computer systems and to provide a consistent experience for patrons. ${ }^{1}$ However, in her article on classification based on sameness and difference, Olson stated,

I would like to build on the idea of diversity rather than universality as a way of accommodating our diverse users and collections and, thus, decreasing levels of bias. To do so requires a variety of approaches-not only can we not have a universal solution, we cannot even have a universal method for achieving solutions. ${ }^{2}$ 
Asking whether librarians generally believe that their local practices for classifying videos adequately helped patrons, what problems librarians experience with video classification, and librarians' perceptions about how their libraries handle classification enabled us to explore these ideas.

\section{Literature Review}

\section{Discoverability}

Classification is essential to making library materials discoverable. Kinney's paper on historical changes in moving image classification recounts the changes in attitude toward classifying audiovisual materials and toward open rather than closed stacks. Switching to open stacks meant that videorecordings became browsable collections that required a user-friendly classification system. ${ }^{3}$ Present guidelines support including nonprint materials in library collections and in library catalogs, using the same classification practices as for books. ${ }^{4}$ While classification data are not well used in current catalog systems, Kinney references Calhoun to state that its use "to support browsing by subject is among the proposed steps for revitalizing the catalog." Kinney references Handman's argument that media materials are educationally significant, relatively unique, and complex in terms of bibliographic description and access requirements, all of which means that there should be more core cataloging elements for media than for books. ${ }^{6}$

\section{Record Quality}

The Survey of Academic Library Cataloging Practices, conducted in 2011 by the Primary Research Group, found that 95.71 percent of the seventy libraries surveyed performed video cataloging in-house. ${ }^{7}$ One challenge for libraries when classifying videorecordings is that the quality of records available in OCLC varies widely. Not surprisingly, films with the widest distribution tend to have the highest-quality bibliographic records. ${ }^{8}$ But for any given film title, catalogers may be faced with multiple choices when selecting the best quality video record.

To determine the quality of records in their OPAC and whether minimal record editing was sufficient, Myall and Chambers examined the catalogs of Eastern Washington University and Gonzaga University. They found that neither of the catalogs they studied had been able to import US national-level, full-level records of video resources without editing. Librarians at those institutions perform minimal institutional-level editing of videorecords to conform to OCLC's requirements for full cataloging (I-Level). ${ }^{9}$ The average videorecording record required about six edits, as compared to two edits for print monographs. The fields requiring the most additions or corrections were not identified. Not surprisingly, when the encoding levels decreased in completeness, more additions and edits were required. The study also noted that most records have been modified by multiple libraries in addition to the Library of Congress (LC). This suggests that one cannot simply rely on a recordmatching method of copy cataloging for videorecordings. Videorecording cataloging requires catalogers with knowledge of both the cataloging practices and the motion picture industry. Myall and Chambers recommended establishing "a national cooperative program to provide authoritative cataloging records for videos," which "could also develop a larger, more widely distributed, and more knowledgeable cohort of audiovisual catalogers as well as improve the accuracy, completeness, and consistent treatment of bibliographic records for these materials." ${ }^{\prime 10}$

In some ways, groups such as OLAC (Online Audiovisual Catalogers) have engaged in this type of work. However, their current video cataloging guidelines, Best Practices for Cataloging DVD-Video and Blu-ray discs using RDA and $M A R C 21$, addresses neither classification nor subject or genre headings. ${ }^{11}$

\section{Circulation Decisions}

Kinney referenced Ho's 2004 study that found that " 73 percent of ARL libraries and 39 percent of all libraries surveyed shelved their video collections in closed stacks." ${ }^{.12}$ Also circa 2004, Laskowski and Bergman noted that a growing number of institutions allowed students to check out videos for use outside of the library. They stated that at one institution, policies changed because of "the discrepancy in encouraging students to make use of videos for class presentations while making it difficult for them to access these media materials."13

\section{Classification Decisions Related to Serving Underrepresented Communities}

\section{Accession Numbers}

Library policies evolved to treat videorecordings as full members of the library collection, compared to 1989 when Scholtz advocated including videorecordings in the library's catalog. ${ }^{14}$ While most libraries now include videorecordings in their catalogs, many still use basic accession numbers to organize these materials, in contrast to the fully classified by subject print materials. ${ }^{15}$ Like classification numbers, accession numbers indicate specifically where videos are located in the collection. Unlike classification numbers, accession numbers reflect only the sequence in which those materials were processed, with no other contextual information. This 
practice requires little time or skill to apply, and can be helpful for inventory purposes. Using accession numbers to organize videos can cause challenges for patrons because it does not allow for shelf browsing by subject or alphabetically, and is used predominantly by libraries with closed stacks. ${ }^{16}$ Kinney's work supports the interpretation, "The best that can be said for shelving by accession numbers is that it may make for cheaper and faster cataloging.",17

\section{Formal Classification Structures}

Bowker and Star, in their influential book Sorting Things Out, noted that "information scientists work every day on the design, delegation, and choice of classification systems and standards, yet few see them as artifacts embodying moral and aesthetic choices that in turn craft people's identities, aspirations, and dignity." 18 They identified the elements of a formal classification system: consistent principles, mutually exclusive categories, and complete descriptions of the area it covers. In actual practice, classification systems do not operate according to these ideals. Local modifications to Library of Congress Classification (LCC), local shelving decisions, and classification choices based on misunderstandings or disagreements with the structure, illustrate how a library's individual decisions make classification a complex process.

Olson's research supports those ideas. She argues that no classification system is ever completely inclusive. Classification systems such as LCC are created on the basis of literary warrant, and "what gets published is also limited by powerful social discourses, it too tends to produce a corpus largely representing mainstream thought."19

One of these classification oversights relates specifically to video cataloging. Dewey Decimal Classification (DDC) and LCC schemes are not designed to accommodate nonprint materials. This is notably problematic for fiction television programs and films, which are often squeezed into LCC's PN schedule as examples of things that are drama amid nonfiction titles about drama. It is also a problem for other moving image materials. Kinney discussed various options to modify LCC's existing structure for music materials, suggesting possibilities such as including classifying musical performances with the same number that the print version would receive and Cuttering videorecordings of operas and other works by composer rather than title. ${ }^{20}$ An example of a local modification from the authors' own library is to treat the director as the primary creator using the literature schedule. This works well for film studies favorites such as Hitchcock and Kurosawa. However, the Harry Potter films, which patrons would reasonably expect to be shelved together, but which had different directors, were separated both in our modified version of LCC and in strict LCC. We have therefore made selective modifications to local practices to ensure that all the Marvel Avengers films are shelved together and that the Harry Potter series is collocated. The practices surrounding classification of videorecordings are different from those for print monographs. While it would be ideal if standards reflected those differences, they currently do not.

\section{Problems in Classification Structures}

Classification encourages browsing and discovery in a way that is not possible using accession number and closedstacks arrangements. ${ }^{21}$ The construction of those classification systems occurs within the confines of the culture(s) in which they are developed. Olson argued that "[people] take the classification for granted as though it were a natural landscape rather than a well-manicured lawn that is the product of intellectual labor." ${ }^{\text {"2 }}$ Intellectual labor can reify the unconscious biases of its creators. ${ }^{23}$

Referring specifically to items physically shelved in libraries, Olson noted that those items are limited to the linear space in which each item is assigned one defining classification number/code, with distinct boundaries between classification numbers/codes. ${ }^{24}$ Making the choice to include or exclude something from that space is never a neutral act. Another classification problem sometimes faced by video catalogers is how to assign responsibility when many people are involved in a film's creation. Classification systems based on a single-author Cutter are not optimal in this situation. While strictly following LCC and Cuttering videorecordings by title does not cause this problem, it can be challenging for libraries that modify LC rules to Cutter by director (or other creator). This problem is not unique to big budget Hollywood films. Discussing DDC's treatment of folklore, Olson notes that Western cultures prioritize the individual over the collective, even when a particular work is created by multiple people within a longstanding cultural tradition. ${ }^{25}$

Comparing how groups such as gays and lesbians are treated by classification systems, Olson and Ward argued that DDC's structure creates spatial gaps, or diasporas, between corresponding topics by assigning similar but distinct subclasses. ${ }^{26}$ Similar concerns occur within LCC. For example, films about men generically and white men specifically are classed in HQ1090, while films about black men are often classed in E185. This suggests that white men is the default in the first classification area. This same process effectively racializes films about black men racialized in a manner not applied to films about white men.

\section{Streaming Video}

The adoption of streaming video in libraries has changed user expectations. Educational use of video resources on campus has accelerated across all disciplines, and even as 
recently as five years ago, faculty, librarians, and administrators anticipated that use of video resources in education would grow significantly. There was the problem that "technology, legal, and other barriers continues to thwart faculty finding and accessing the segments of video they want for teaching and lectures." ${ }^{, 27}$ Researchers also identified a clear need from those working in higher education for an online video repository that could be accessed as needed. ${ }^{28}$ In this case, that need surpasses the minimal service found through vendors such as Netflix. Convenience is the primary interest reason to use streaming video, but there is also interest in the added value that can be included, such as transcripts and the ability to create a playlist of specific film clips. ${ }^{29}$ For teaching and related purposes, users require high quality metadata about content, usage rights, format, and platform specifications, in addition to streaming video resources being reliable enough for classroom use.

Classification of free streaming videos of lectures and from major research institutions is important. ${ }^{30}$ While these lectures are usually posted on video sites, author-provided metadata are not always as user-oriented as that provided by professionals. Creating records for these videos in OCLC will allow us to facilitate patrons' access to these important resources.

The use of streaming video has already reached the tipping point in the majority of academic libraries licensing at least some streaming video. Data from the 2010 Primary Research Group survey indicated that across all Carnegie classifications of Institutions of Higher Education, approximately 33 percent of academic libraries provided streaming video. ${ }^{31}$ Whereas results of the 2013 Survey of Academic Streaming Video (SASV) conducted by Farrelly and Hutchinson showed an increase to 70 percent of all academic libraries providing some streaming video, and most of the remaining libraries planned to do so within three years. ${ }^{32}$

SASV results also found that libraries use a wide variety of tools, including the OPAC, discovery layers, and LibGuides, to provide access to streaming videos. Librarians who responded to the survey expressed their preference for using the online catalog to search for streaming videos because of title-specific searching. However, 25 percent of respondents did not provide catalog access to streaming videos, and only 41 percent used the catalog as the primary access point. Licensing restrictions were cited by respondents as one reason streaming video was not being included in their catalog, but the major reason appears to be inadequate staff time being devoted to managing streaming video. As stated by Farrelly and Hutchinson,

Librarians are largely unaware of many factors related to streaming video. Many librarians are unfamiliar with models, practices, systems, and other factors related to the acquisition and support of streaming videos in their collections. Significantly, librarians overwhelmingly report relatively low level of staff time to support streaming video. In the aggregate, for selection, licensing, encoding and uploading, and metadata, respondents report a staff commitment of less than one full-time equivalent. More than a quarter of respondents, however, report not knowing what that commitment is. ${ }^{33}$

\section{Method}

During a presentation the authors made at a state conference, librarians and library staff in attendance disclosed a variety of local practices for videorecordings. This inspired us to ask a larger audience of librarians whether most believed that their local practices for classifying videos adequately helped their patrons; what problems librarians experience with video classification, such as inconsistent categories or bias; and librarians' perceptions about how their libraries handle classification.

To increase our understanding of the existing variety of classification and shelving practices for videos, we developed a survey. Because our intention was to capture diverse perspectives that we might not otherwise have considered, we intentionally solicited responses from a broad array of librarians. Our reason for implementing this survey was to have a diverse sample of responses. We knew that surveys using convenience sampling are often ungeneralizable, but diverse convenience samples increase their usefulness. Diverse sampling ensure that a broad range of potential participants are invited, and provide similar attitudinal results as one finds from probabilistic samples. ${ }^{34}$ Catalogers and public services librarians bring different insights, as do public librarians and academic librarians. Since our goal was to learn about participants' practices and opinions, we permitted open textual responses for many of the questions in addition to listed response options. A copy of the survey is in the appendix.

The questionnaire consisted of two sections. The first section was on demographics: the kind of libraries the respondents represented and the location of these libraries. The second section was the decisions that respondents made about video classification: the kinds of videos classified, where videos are shelved, what classification standards are used, and how satisfied respondents are with the classification standards they use.

We used Qualtrics (www.qualtrics.com) to disseminate and analyze the survey results. To solicit the broad response we desired, links to the survey were posted to email discussion lists for catalogers, media librarians and generalists, including OCLC-CAT, OLAC-L, VideoLib and colllib-l. The researchers also shared survey links on their personal 
Table 1. Are Your Videos on Open Stacks? (i.e., patrons can go to the shelves and select their own videos)

\begin{tabular}{|c|c|c|c|c|c|c|}
\hline & $\begin{array}{c}\text { Academic } \\
\text { Libraries }\end{array}$ & Public Library & Special Library & $\begin{array}{c}\text { School (K-12) } \\
\text { Library }\end{array}$ & Other & Total \\
\hline Yes & 148 & 81 & 13 & 3 & 9 & 254 \\
\hline Some & 65 & 6 & 1 & 2 & 1 & 75 \\
\hline Total & 302 & 87 & 23 & 6 & 16 & 434 \\
\hline
\end{tabular}

Table 2. Are Your Videos Integrated with Other Formats?

\begin{tabular}{|c|c|c|c|c|c|c|}
\hline & $\begin{array}{c}\text { Academic } \\
\text { Libraries }\end{array}$ & Public Library & Special Library & $\begin{array}{c}\text { School (K-12) } \\
\text { Library }\end{array}$ & Other & Total \\
\hline Yes & 28 & 5 & 9 & 1 & 4 & 47 \\
\hline Some & 44 & 18 & 5 & 1 & 3 & 71 \\
\hline Total & 302 & 87 & 23 & 6 & 16 & 434 \\
\hline
\end{tabular}

Facebook or Twitter pages. In the two-week response period (January 12-23, 2015), 412 surveys were completed.

\section{Results}

Respondents were primarily from academic libraries (7 percent from two-year colleges, 17 percent from four-year colleges, and 45 percent from universities, totaling 69 percent of responses). Because there were no real differences in percentages for how the academic libraries responded, they are grouped as "academic" for discussion of the survey results. Twenty percent of responses were from public libraries, 1 percent were from school libraries, 5 percent were from special libraries, and 4 percent were from other types of libraries. Several of the "other library" responses were from law librarians. Regarding location, 98 percent of respondents were from North America, 1 percent were from Europe, and 1 percent were from elsewhere.

The authors based the survey questions on ideas discussed during our conference presentation and identified through a literature review. Questions were oriented around decisions various library types make about physical access, streaming access, and classification. Because the questionnaire was distributed to individuals and participants were not required to list their institutional affiliation, it is possible that multiple librarians from the same institution answered the survey. The goal was to capture a diverse array of perspectives, so we did not consider this a barrier. While the survey was open to all library types, the number of responses from the school, special, and other library categories were too small to be meaningful when separated from the whole. Therefore we have chosen to present only separate responses from public and academic libraries.

\section{Physical Access}

Our previous research indicated that shelving and checkout policies often affect whether collections are classified with call numbers. ${ }^{35}$ Therefore we included questions about these practices in the survey.

\section{Open or Closed Stacks}

Not surprisingly, all public librarians that responded indicated that their libraries shelve videos in open stacks. Half of the academic librarian responses indicated that their video collections are in open stacks, with an additional 22 percent using a mixed open/closed stack arrangement for portions of the collection. Comments added by respondents indicating mixed open/closed stack shelving included a variety of configurations, such as popular fiction titles are in open stacks, while more expensive educational DVDs are kept in closed stacks. In other cases, VHS tapes have been moved to open stacks. Some libraries display DVD cases in open stacks while retaining the actual DVD behind a service desk. Table 1 shows numerical results.

\section{Format Integration}

Most librarians (73 percent) indicated that their libraries do not integrate videos with other formats. But 7 percent of public library respondents and 12 percent of academic library respondents do integrate videos with other formats, with the integrated shelving generally being used for nonfiction videos (see table 2). Comments showed processing variations in cases when DVDs are treated as accompanying materials to books. 
Table 3. Who Can Checkout Videos?

\begin{tabular}{|c|c|c|c|c|c|c|}
\hline & $\begin{array}{l}\text { Academic } \\
\text { Libraries }\end{array}$ & Public Library & $\begin{array}{l}\text { Special } \\
\text { Library }\end{array}$ & $\begin{array}{l}\text { School }(K-12) \\
\text { Library }\end{array}$ & Other & Total \\
\hline Students & 261 & 9 & 8 & 4 & 5 & 287 \\
\hline Faculty & 271 & 8 & 6 & 6 & 6 & 297 \\
\hline Community Members & 131 & 72 & 3 & 2 & 5 & 213 \\
\hline In-Library Use Only & 9 & 1 & 2 & 0 & 3 & 15 \\
\hline Not Applicable & 0 & 0 & 0 & 0 & 2 & 2 \\
\hline Other & 60 & 18 & 9 & 1 & 3 & 91 \\
\hline $\begin{array}{l}\text { Some Mix Depending on } \\
\text { Material Type and User Type }\end{array}$ & 46 & 4 & 3 & 0 & 0 & 53 \\
\hline
\end{tabular}

Table 4. How Do You Classify Videos at Your Library?

\begin{tabular}{lcccccc}
\hline & Academic & Public & Special & School (K-12) & Other & Total \\
$\begin{array}{l}\text { Library of } \\
\text { Congress (LCC) }\end{array}$ & 183 & 5 & 9 & 1 & 7 & 205 \\
$\begin{array}{l}\text { Decimal (DDC, } \\
\text { UDC) }\end{array}$ & 27 & 60 & 2 & 4 & 2 & 95 \\
Other & 22 & 12 & 5 & 0 & 2 & 41 \\
Total & 232 & 77 & 16 & 5 & 11 & 341 \\
\hline
\end{tabular}

\section{Check-out Permissions}

The majority of libraries have less restrictive lending policies than revealed in past surveys. ${ }^{36}$ Responses showed that the majority of libraries lend to multiple patron types, including some interlibrary loans. A few still restrict patrons to onsite viewing or faculty-only checkouts. Unfortunately, there appears to have been some confusion about how to answer the question, which resulted in many open-ended descriptions about specific policies (see table 3).

\section{Reserve Shelving}

The survey did not specifically ask about videos in reserve collections. It was assumed that reserve and/or booked videos would be held in restrictive closed stacks. Comments provided by several respondents confirmed this assumption.

\section{Classification}

Most respondents use a formal classification scheme to arrange videos, with almost equal numbers strictly following cataloging rules or making local modifications. The predominant classification schemes are LCC (60 percent) or DDC (28 percent), with percentages similar to the percent of responses from academic libraries and public libraries respectively. Other formal schemes referenced include
Superintendent of Documents (SuDoc) and Medical Subject Headings (MeSH). Two libraries use BISAC subject headings as their classification system. BISAC stands for Book Industry Standards and Communication. Based on open-ended comments added to this question, it appears that BISAC subject descriptions are often used as shelving guides to facilitate browsing within public libraries (see table 4$){ }^{37}$

As previously noted, we allowed respondents to comment on their activities and perceptions to provide a richer understanding of actual practices. In the next section, much of what we describe came from free text responses.

Some respondents reported that the format shift from videotapes to DVDs enabled them to improve local cataloging practices. By shelving DVDs separately from videotapes, and therefore avoiding the laborious process of reclassifying all of their videotapes from accession numbers, they fully classified DVDs as they were added to the collection. Even libraries that still assign accession numbers appear to otherwise fully include DVDs in the catalog.

Unlike nonfiction films (documentaries, etc.), which were almost universally classified using DDC or LCC, there was more variety in how libraries handle fiction films (see tables 5 and 6).

From the survey data, we found that there is not a single way that a majority of libraries classify their fiction videos. However, it is clear that librarians make choices on the basis of their patrons' needs and to maintain consistency 
Table 5. What Kinds of Videos do You Classify?

\begin{tabular}{|c|c|c|c|c|c|c|}
\hline & $\begin{array}{c}\text { Academic } \\
\text { Libraries }\end{array}$ & Public Library & Special Library & $\begin{array}{c}\text { School (K-12) } \\
\text { Library }\end{array}$ & Other & Total \\
\hline Fiction Only & 0 & 0 & 0 & 0 & 0 & 0 \\
\hline Nonfiction Only & 10 & 20 & 3 & 0 & 4 & 37 \\
\hline All of Them & 245 & 62 & 15 & 6 & 8 & 336 \\
\hline None of Them & 34 & 2 & 5 & 0 & 2 & 43 \\
\hline Other & 18 & 4 & 0 & 0 & 2 & 24 \\
\hline Total & 307 & 88 & 23 & 6 & 16 & 440 \\
\hline
\end{tabular}

Table 6. Classification Variations

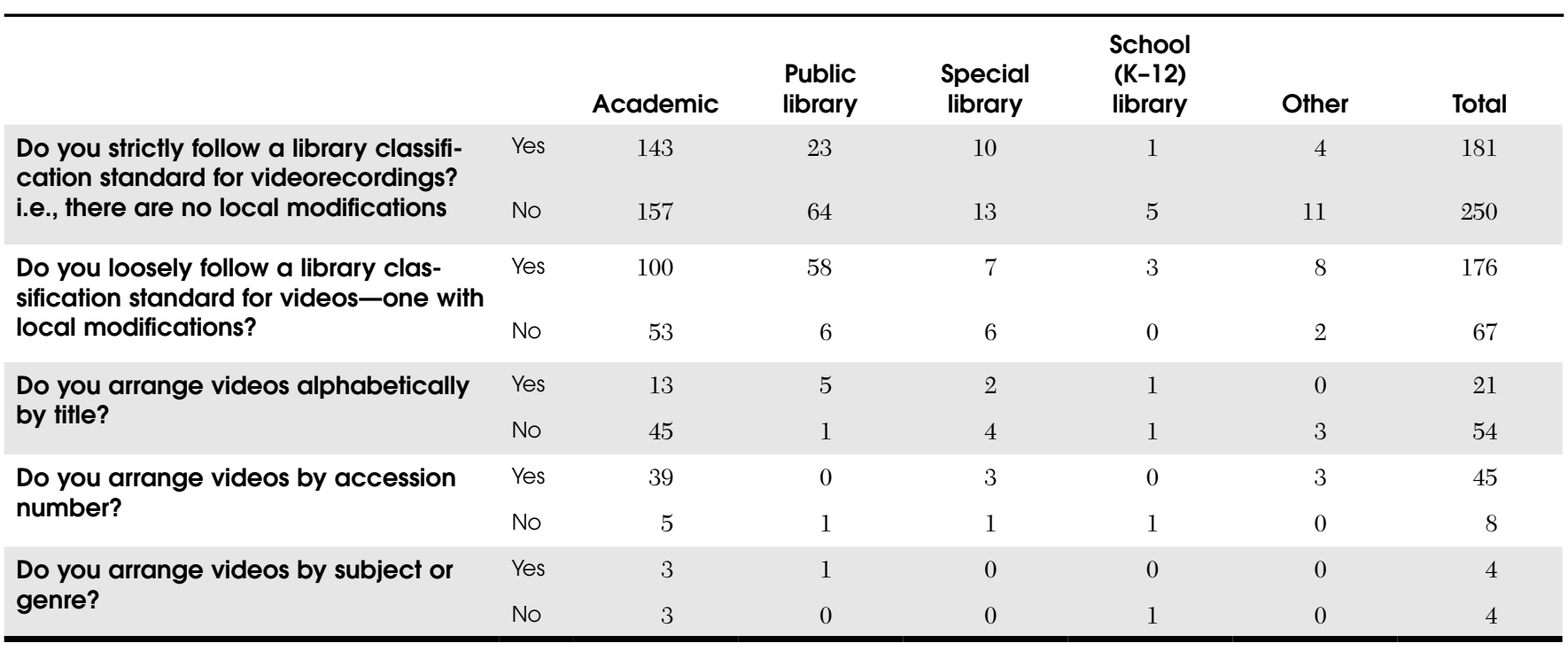

in the stacks. A few respondents noted that their current system was inherited from previous catalogers or administrations and that they would change it if possible, but were constrained by lack of time, money, and staff. Many of the respondents addressed which section of LCC they use to classify their videos. Librarians identified if they were using PN1995.9 to classify their videos by genre or PN1997-1997.2 to class films by their title. PN1997 is used to class films that were created before 2001 and PN1997.2 is used to class films from 2001 to the present. More than one librarian chose to classify all films under PN1997 to have the entire collection in alphabetical order without the separation of years. This type of classification can present challenges when Cuttering for the title as longer Cutter numbers are more difficult to locate and shelve. Multiple librarians mentioned the length of the Cutter as a cause of frustration in their library.

The majority of participants indicated that they are happy with their video classification scheme. Through a five-point Likert scale that used smiley faces to indicate level satisfaction, 83 percent of 325 responses received for this question indicated that they were happy to very happy (4-5) with their classification scheme (see table 7).

This overall satisfaction level was followed with questions regarding what classification problems concerned participants, as shown in table 8.

Again, using a five-point scale, the average value for the prompt "We're pretty happy with how this works for us" was 4.13 ("Sometimes/Always"). On the other end of the scale, 9 percent indicated at least some dissatisfaction with classification. An additional 8 percent responded neutrally. These percentages were consistent across all library types. We also asked whether classifications are too specific or too broad. Seventy percent of respondents indicated that they are "never" or "rarely" too specific. Respondents seemed divided about whether they are too broad. Approximately 30 percent of respondents answered that they are Sometimes too broad and 29 percent of respondents indicated that classifications are "rarely" too broad.

Considering the possibility of providing multiple classification numbers in a streaming environment, we asked whether librarians ever assign multiple classifications. 
Table 7. Satisfaction with Classification

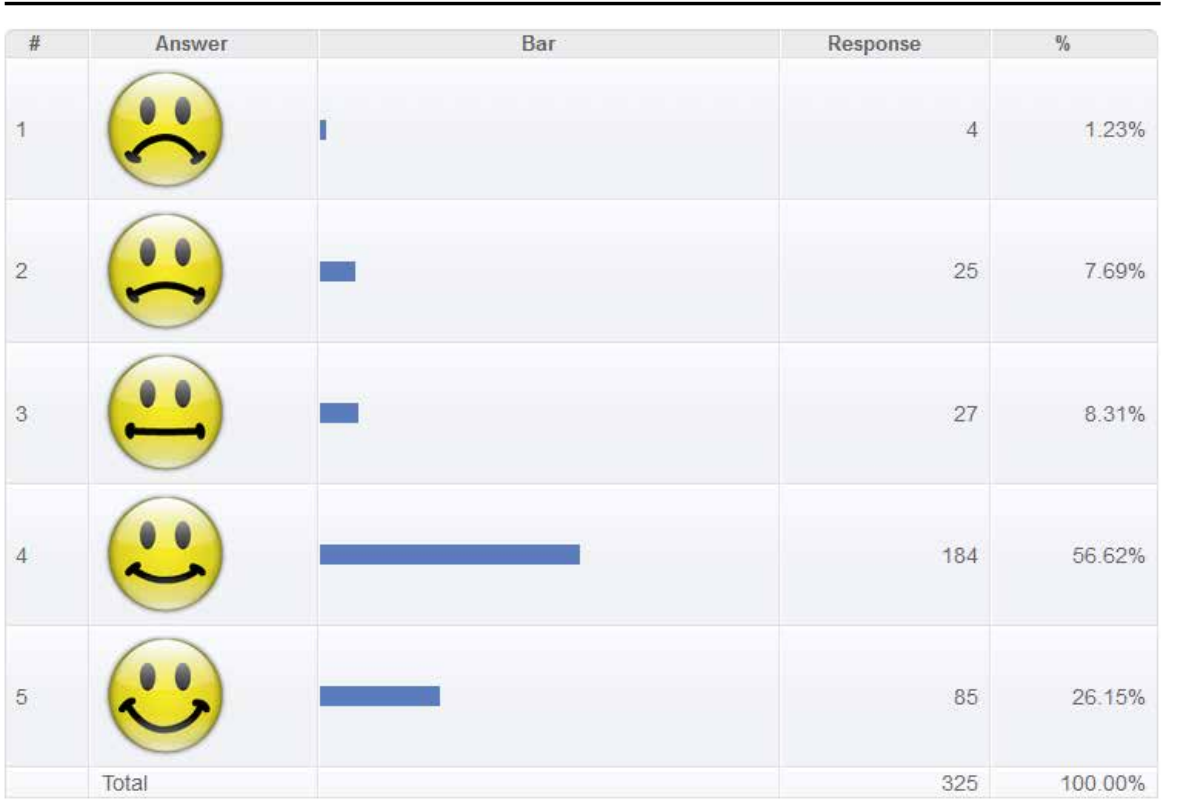

For libraries that do not include streaming videos in the catalog, the primary reasons cited by twenty-seven librarians was that the library did not consider the streaming videos a priority or that they lacked the time and money necessary for this work. Similarly, an additional eleven responses indicated a reliance on vendor databases to provide access to streaming videos rather than including title-level access points to those databases from within the library catalog. Four of the librarians surveyed responded that streaming videos were available only to off-campus students for short-term use and therefore it was unnecessary to add the titles to the catalog.

\section{Discussion}

Seventy-four percent of respondents said that was "never" or "rarely" the case, while only 17 percent indicate that they "sometimes" or "always" want to do so.

The prompt with the least support, with a 1.98 average ("never/rarely"), was "The whole classification scheme seems kind of racist, sexist, ableist, etc.," which 204 of 376 respondents said was never a problem. While one could easily question the wording of this question, as it was intended to elicit an instinctive response. Considering the literature review above, some of which is deeply critical of existing classification schemes because of systemic issues of racism and sexism, we thought it was important to include this perspective. ${ }^{38}$

\section{Streaming Access}

In response to the question, "Does your library purchase access to streaming video?," 64 percent indicated "yes." Of those librarians who responded with "yes," 56 percent were public librarians and 74 percent were academic librarians. Streaming videos are licensed from the vendor in various options for wide ranging lengths of time. Among librarians who indicate that their libraries acquire streaming video, only 67 percent include streaming video titles in their catalog. Comparing library types, we found that only 50 percent of public librarians and 70 percent of academic librarians who offer streaming video also say that they include the records in their catalogs. Compared to the SASV survey, which indicated that 75 percent of libraries offer access to streaming videos through the catalog, we infer that not including all streaming video titles in the catalog is still unfortunately a common situation.
One of the questions that prompted this project was whether librarians believed that local video classification practices adequately help patrons. This study has revealed that the concerns about local video classification practices do not necessarily focus on the lack of uniformity, but the feelings of uncertainty that catalogers and media specialists have about their decisions. While many respondents noted that their video cataloging systems work for the most part, there are still areas that require more consideration. Areas that are particularly in need of further study include how to better represent genre for patron discovery and how to classify video adaptations of film and other formats.

Whether the library chooses to class using PN1995.9 or PN1997, the main issue is that they must constantly create their own Cutters for the film to fit into their collection, which can be time consuming and requires a professional cataloger. As the Primary Research Group noted in their report, only 4.29 percent of academic libraries in 2011 were outsourcing their video cataloging, while 44.29 percent of libraries outsourced their e-book cataloging. ${ }^{39}$

For the questions that asked about bias in classification, responses were as anticipated. Because of the sensitive nature of this area, we were also unsure whether participants would answer on the basis of their conscious thought processes rather than their automatic valuations, which Hofmann et al. found to be more reliably represented when participants answer spontaneously. ${ }^{40}$ After seeing the strongly negative response to this prompt, we wondered if there were differences in perspective by library types. However, this did not seem to be the case: the "never" responses was selected by 54 percent of academic librarians, and 49 
Table 8. Classification Opinions

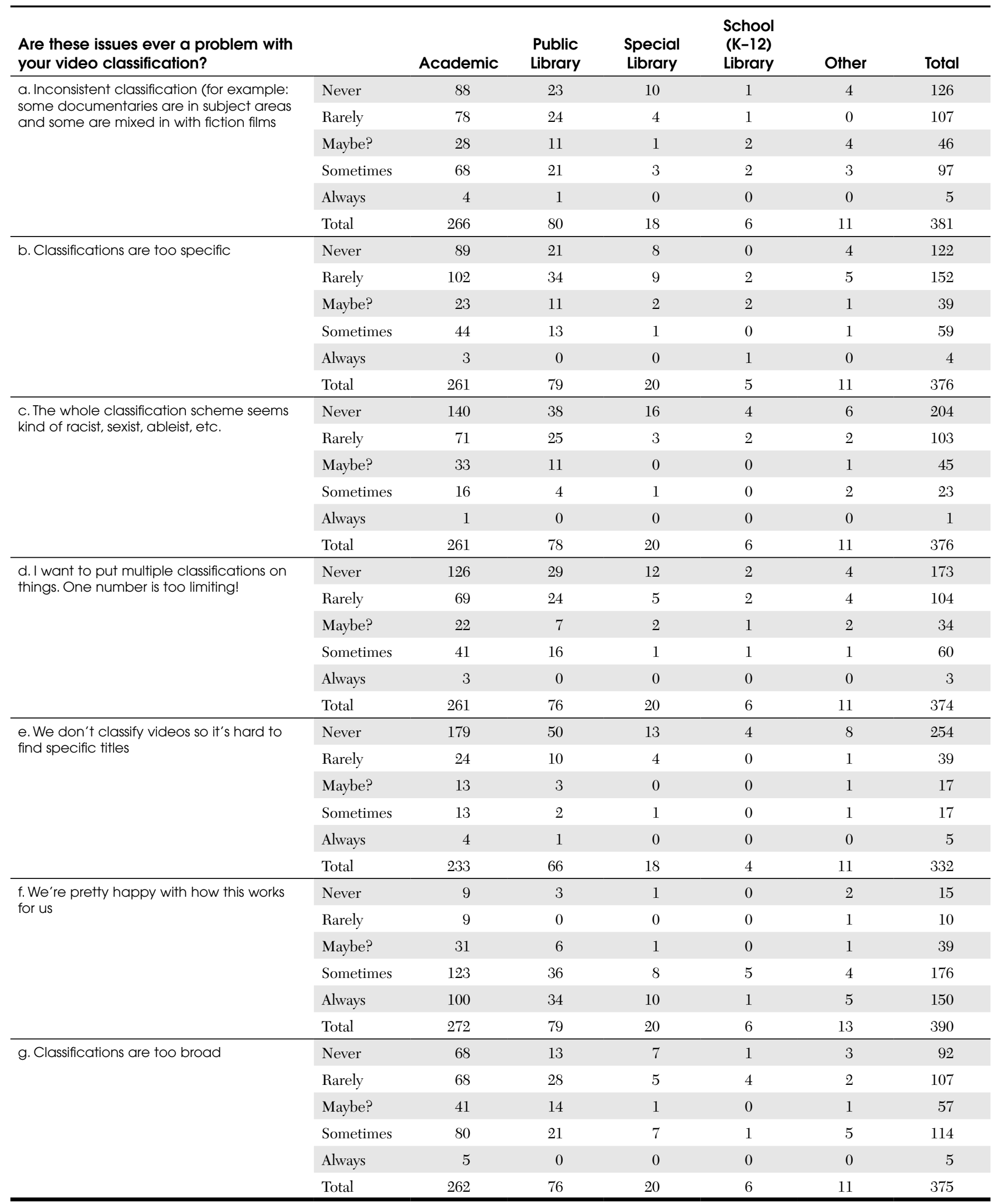




\begin{tabular}{|c|c|c|c|c|c|c|c|}
\hline & & Academic & Public Library & $\begin{array}{l}\text { Special } \\
\text { Library }\end{array}$ & $\begin{array}{c}\text { School (K-12) } \\
\text { Library }\end{array}$ & Other & Total \\
\hline \multirow{2}{*}{$\begin{array}{l}\text { Does your library pur- } \\
\text { chase access to stream- } \\
\text { ing videos? }\end{array}$} & No & 81 & 39 & 21 & 4 & 14 & 159 \\
\hline & Total & 306 & 88 & 23 & 6 & 16 & 439 \\
\hline \multirow{2}{*}{$\begin{array}{l}\text { Do all streaming video } \\
\text { titles appear in the cata- } \\
\text { log? }\end{array}$} & No & 67 & 24 & 1 & 1 & 0 & 93 \\
\hline & Total & 225 & 48 & 2 & 2 & 2 & 279 \\
\hline
\end{tabular}

percent of public librarians. Based on the comments, including one participant who was appalled at the other suggestion and one participant who expressed resignation about it, this appears to be a good area for further investigation through a more interactive method.

Demand for streaming video has grown quickly, requiring vendors and libraries to change their business models to include licensing access. Survey responses confirm that many libraries are licensing access to streaming video. The rapid changes in streaming video offerings and license options, especially in the availability of large subscription packages of films without concurrent staffing additions, have caused libraries to lag behind in including complete holdings in the catalog. From these results, we can make certain conclusions about the hierarchy of streaming videos compared to other library materials. It also raises questions about the purpose of streaming videos in libraries being used as support materials for a course. Survey respondents appear to recognize that streaming video resources should be in the catalog, but library processes and procedures need time to catch up, especially staff time assigned to this work. In 2015, Hutchison and Farrelly conducted a follow-up to their 2013 survey, the results of which we anticipate will show considerable changes in just two years. ${ }^{41}$ For example, the licensing platform Kanopy has made huge inroads into hosted video content with a large number of video vendors, but was not yet available to US libraries in 2013. The recent addition of on-demand and evidence-based licensing options by several vendors greatly increases streaming licensing options for libraries.

\section{Conclusion}

The only clear conclusion reached from this survey is that there is not one consistent way to handle videorecordings in libraries and certainly no one right way. Libraries have generally increased their comfort level with managing videos as a more equal part of their collections, but in some ways the processes for handling these materials have not advanced greatly from the time when libraries began acquiring videotapes twenty-five years ago. Many academic libraries still use closed stacks and accession numbers for physical items, although that number is decreasing for both. The increasing availability of streaming video is changing how films are acquired and made discoverable and accessible. As libraries have seen with e-journals and e-books, we are now increasingly providing licensed access as opposed to owning a physical item. As libraries shift to a focus on virtual browsing, they will need to reevaluate how those films are classified. At this point, a substantial number of both academic and public libraries do not include bibliographic records for streaming video in their catalogs.

One topic that emerged from the questions related to problems librarians experience with videorecording classification is how systemic discrimination is manifested within classification schedules. While this survey suggests that it is not a major concern for most librarians, cataloging research suggests that it is an important issue for users. To overcome limitations within the survey method when asking potentially sensitive questions, we suggest using qualitative methods including a discourse analysis of classification decisions, reflexive case studies, interactive interviewing, or focus groups with library patrons from marginalized populations.

In a related note, there may be differences in patron perceptions of video classification processes when compared to library employee perceptions. User studies examining patron efficacy and comfort with library terminology, organizational structures, and spaces are an important area that needs considerable investment in the future.

\section{References}

1. Lois Mai Chan and Marcia Lei Zen, "Metadata Interoperability and Standardization: A Study of Methods Part I, Achieving Interoperability at the Schema Level," D-Lib Magazine 12, no. 6 (2006), www.dlib.org/dlib/june06/chan/06chan .html.

2. Hope A. Olson, "Sameness and Difference: A Cultural Foundation of Classification," Library Resources \& Technical Services 43, no. 3 (2001): 121. 
3. Daniel W. Kinney, "The Classification of Music Moving Image Materials: Historical Perspectives, Problems, and Practical Solutions," Cataloging \& Classification Quarterly 47, no. 1 (2009): 2-22, http://dx.doi.org/10.1080/01639370802451975.

4. Association of College and Research Libraries, American Library Association, Guidelines for Media Resources in Academic Libraries (Chicago: American Library Association, 2012), accessed June 2, 2015, www.ala.org/acrl/standards/ mediaresources.

5. Kinney, "The Classification of Music Moving Image Materials," 8.

6. Gary Handman, "I Lost It (or Found It) at the Movies: Public Service Implications of Minimal-Level Cataloging of Audiovisual Materials," Technical Services Quarterly 9, no. 2 (1991): 39-47.

7. Primary Research Group, The Survey of Academic Library Cataloging Practices (New York: Primary Research Group, 2011).

8. Barb Bergman, Jessica Schomberg, and Victoria Peters, "Video Collecting for the Sometimes Media Librarian: Tips and Tricks for Selecting, Purchasing, and Cataloging Videos for an Academic Library," College \& Undergraduate Libraries 14, no. 1 (2007): 57-77.

9. Carolynne Myall and Sydney Chambers, "Copy Cataloging for Print and Video Monographs in Two Academic Libraries: A Case Study of Editing Required for Accuracy and Completeness," Cataloging \& Classification Quarterly 44, no. 3-4 (2007): 233-57, http://dx.doi.org/10.1300/J104v44n03_06.

10. Ibid., 252.

11. "Best Practices for Cataloging DVD-Video and Blu-ray Discs using RDA and MARC21," OLAC, accessed October 18, 2015, http://olacinc.org/drupal/capc_files/DVD_RDA_ Guide.pdf.

12. Kinney, "The Classification of Music Moving Image Materials," 6.

13. Mary Laskowski and Barb Bergman, "Academic Media Center Collection Development and Circulation Policies: A Comparative Analysis," College \& University Media Review 10, no. 2 (2004): 86.

14. James Scholtz., Developing and Maintaining Video Collections in Libraries (Santa Barbara, CA: ABC-CLIO, 1989).

15. Bergman, "Making the Most of Your Video Collection," 33548.

16. Bergman, Schomberg, and Peters, "Video Collecting for the Sometimes Media Librarian," 57-77.

17. Kinney, "The Classification of Music Moving Image Materials," 10.

18. Geoffrey C. Bowker and Susan Leigh Star, Sorting Things Out: Classification and Its Consequences (Cambridge, MA: The MIT Press, 1999): 4.

19. Hope A. Olson, "Mapping Beyond Dewey’s Boundaries: Constructing Classificatory Space for Marginalized Knowledge Domains," Library Trends 47, no. 2 (1998): 235-36.
20. Kinney, "The Classification of Music Moving Image Materials," 11 .

21. Ibid., 10 .

22. Olson, "Sameness and Difference," 115.

23. Olson, "Mapping Beyond Dewey’s Boundaries," 233-34.

24. Ibid., 245.

25. Olson, "Sameness and Difference," 118.

26. Hope A. Olson and Dennis B. Ward, "Ghettoes and Diaspora in Classification: Communicating Across the Limits," in Bernd Frohmann, ed., Communication and Information in Context: Society, Technology, and the Professions (Toronto, Ontario, Canada: Canadian Association for Information Science, 1997): 27, www.cais-acsi.ca/ojs/index.php/cais/article/ download/185/359.

27. Peter B. Kaufman and Jen Mohan, "Video Use and Higher Education: Options for the Future," (New York: Intelligent Television and Copyright Clearance Center, 2009): 2, https:// library.nyu.edu/about/Video_Use_in_Higher_Education.pdf.

28. Ibid., 11.

29. Matt Enis, "On Demand Academic Streaming Media," Library Journal, October 15, 2015, http://j.libraryjournal .com/2015/10/books-media/on-demand-academic-media.

30. George Wrenn, "Hidden in Plain Sight? Records for onDemand Academic Public Lectures in OCLC WorldCat: A Survey," Cataloging \& Classification Quarterly 48, no. 8 (2010), http://dx.doi.org/10.1080/01639374.2010.492465.

31. Primary Research Group, Library Use of Video and Audio (New York: Primary Research Group, 2011).

32. Deg Farrelly and Jane Hutchison, "Academic Library Streaming Video: Key Findings from the National Survey," Against The Grain 26, no. 5 (2014): 73.

33. Ibid., 75.

34. Samuel J. Best et al., "An Assessment of the Generalizability of Internet Surveys," Social Science Computer Review 19, no. 2 (2001): 131-45.

35. Barb Bergman, "Making the Most of Your Video Collection: Trends in Patron Access and Resource Sharing," Library Trends 58, no. 3 (2010): 335-48.

36. Bergman. "Making the Most of Your Video Collection," 33548.

37. “Tutorial and FAQ," Book Industry Study Group, accessed October 18, 2015, https://www.bisg.org/tutorial-and-faq.

38. Olson, "Sameness and Difference," 115.

39. Primary Research Group, The Survey of Academic Library Cataloging Practices, 2011-12 ed. (New York: Primary Research Group, 2011), 108-9.

40. Wilhelm Hofmann et al., "A Meta-Analysis on the Correlation between the Implicit Association Test and Explicit Self-Report Measures," Personality \& Social Psychology Bulletin 31, no. 10 (2005): 1369-85, http://dx.doi.org/ $10.1177 / 0146167205275613$.

41. Enis, "On Demand Academic Streaming Media." 


\section{Appendix. Video Classification Survey}

1. Do you want to take this survey?

\section{Demographic Information}

2. What type of library organization do you work for?

$\circ$ 2-Year College or equivalent

○ 4-Year College

$\circ$ University

○ Public library

○ Special library

O School (K-12) library

o Vendor

o Other

3. Location?

And now to the real questions ...

We are going to use the words video and videorecording to include all formats of this type: VHS, DVD, film, streaming, etc.

4. The way that your organization is structured, where does the cataloging occur?

$\circ$ Off-site cataloging department

○ In-house cataloging department

o We purchase catalog records, we don't have a cataloging department

o Other

5. Who can check out videos? (Check all that apply)

o Students

$\circ$ Faculty

$\circ$ Community members

$\circ$ No one-in library use only

○ Not applicable

o Some mix depending on material type and user type that I'll describe here

o Other

6. What kinds of videos do you classify?

$\circ$ Fiction only

$\circ$ Nonfiction only

$\circ$ All of them

o None of them

o Other

7. Does your library purchase access to streaming videos?

$\circ$ Yes

O No

8. Do all streaming video titles appear in the catalog?

$\circ$ Yes

$\circ$ No
9. You indicated that not all streaming titles are displayed in your catalog. Why not?

10. Are your videos on open stacks? (i.e., patrons can go to the shelves and select their own videos without mediation)

$\circ$ Yes

$\circ$ No

o Some of them

11. Are your videos integrated with other formats?

$\circ$ Yes

$\circ$ No

○ Some of them

12. Do you strictly follow a library classification standard for videorecordings? i.e., there are no local modifications

$\circ$ Yes

$\circ$ No

13. Do you loosely follow a library classification standard for videos - one with local modifications?

$\circ$ Yes

$\circ$ No

14. Do you arrange videos alphabetically by title?

$\circ$ Yes

$\circ$ No

15. Do you arrange videos by accession number?

$\circ$ Yes

$\circ$ No

16. Do you arrange videos by subject or genre?

$\circ$ Yes

$\circ$ No

17. Do you put videos on the shelves in no particular order?

$\circ$ Yes

$\circ$ No

18. How do you classify videos at your library?

$\circ$ Library of Congress (LCC)

$\circ$ Decimal (DDC, UDC)

$\circ$ BISAC

O Other

19. What kinds of local modifications do you use? (for example: you follow LCC for non-fiction films but modify how you treat fiction films)

20. How do you choose what subjects/genres to organize videos into?

21. How happy are you with the classification standard that your library uses for videorecordings?

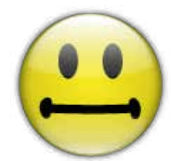


22. Are these issues ever a problem with your video classification?

\begin{tabular}{|c|c|c|c|c|c|}
\hline & Never & Rarely & Maybe? & Sometimes & Always \\
\hline $\begin{array}{l}\text { Classifications are too } \\
\text { broad }\end{array}$ & $\begin{array}{l}\text { Classifications } \\
\text { are too broad Never }\end{array}$ & $\begin{array}{l}\text { Classifications } \\
\text { are too broad Rarely }\end{array}$ & $\begin{array}{l}\text { Classifications } \\
\text { are too broad } \\
\text { Maybe? }\end{array}$ & $\begin{array}{l}\text { Classifications } \\
\text { are too broad Some- } \\
\text { times }\end{array}$ & $\begin{array}{l}\text { Classifications } \\
\text { are too broad Always }\end{array}$ \\
\hline $\begin{array}{l}\text { We're pretty happy with } \\
\text { how this works for us }\end{array}$ & $\begin{array}{l}\text { We're pretty } \\
\text { happy with how this } \\
\text { works for us Never }\end{array}$ & $\begin{array}{l}\text { We're pretty } \\
\text { happy with how this } \\
\text { works for us Rarely }\end{array}$ & $\begin{array}{l}\text { We're pretty } \\
\text { happy with how this } \\
\text { works for us Maybe? }\end{array}$ & $\begin{array}{l}\text { We're pretty } \\
\text { happy with how this } \\
\text { works for us Some- } \\
\text { times }\end{array}$ & $\begin{array}{l}\text { We're pretty } \\
\text { happy with how this } \\
\text { works for us Always }\end{array}$ \\
\hline $\begin{array}{l}\text { I want to put multiple } \\
\text { classifications on things. } \\
\text { One number is too limiting! }\end{array}$ & $\begin{array}{l}\text { I want to put } \\
\text { multiple classifica- } \\
\text { tions on things. One } \\
\text { number is too limit- } \\
\text { ing! Never }\end{array}$ & $\begin{array}{l}\text { I want to put } \\
\text { multiple classifica- } \\
\text { tions on things. One } \\
\text { number is too limit- } \\
\text { ing! Rarely }\end{array}$ & $\begin{array}{l}\text { I want to put } \\
\text { multiple classifica- } \\
\text { tions on things. One } \\
\text { number is too limit- } \\
\text { ing! Maybe? }\end{array}$ & $\begin{array}{l}\text { I want to put } \\
\text { multiple classifica- } \\
\text { tions on things. One } \\
\text { number is too limit- } \\
\text { ing! Sometimes }\end{array}$ & $\begin{array}{l}\text { I want to put } \\
\text { multiple classifica- } \\
\text { tions on things. One } \\
\text { number is too limit- } \\
\text { ing! Always }\end{array}$ \\
\hline $\begin{array}{l}\text { We don't classify videos so } \\
\text { it's hard to find specific titles }\end{array}$ & $\begin{array}{l}\text { We don't classify } \\
\text { videos so it's hard to } \\
\text { find specific titles } \\
\text { Never }\end{array}$ & $\begin{array}{l}\text { We don't classify } \\
\text { videos so it's hard to } \\
\text { find specific titles } \\
\text { Rarely }\end{array}$ & $\begin{array}{l}\text { We don't classify } \\
\text { videos so it's hard to } \\
\text { find specific titles } \\
\text { Maybe? }\end{array}$ & $\begin{array}{l}\text { We don't classify } \\
\text { videos so it's hard to } \\
\text { find specific titles } \\
\text { Sometimes }\end{array}$ & $\begin{array}{l}\text { We don't classify } \\
\text { videos so it's hard to } \\
\text { find specific titles } \\
\text { Always }\end{array}$ \\
\hline $\begin{array}{l}\text { Classifications are too } \\
\text { specific }\end{array}$ & $\begin{array}{l}\text { Classifications } \\
\text { are too specific } \\
\text { Never }\end{array}$ & $\begin{array}{l}\bigcirc \text { Classifications } \\
\text { are too specific } \\
\text { Rarely }\end{array}$ & $\begin{array}{l}\text { Classifications } \\
\text { are too specific } \\
\text { Maybe? }\end{array}$ & $\begin{array}{l}\text { Classifications } \\
\text { are too specific } \\
\text { Sometimes }\end{array}$ & $\begin{array}{l}\text { Classifications } \\
\text { are too specific } \\
\text { Always }\end{array}$ \\
\hline $\begin{array}{l}\text { The whole classification } \\
\text { scheme seems kind of } \\
\text { racist, sexist, ableist, etc. }\end{array}$ & $\begin{array}{l}\text { The whole clas- } \\
\text { sification scheme } \\
\text { seems kind of racist, } \\
\text { sexist, ableist, etc. } \\
\text { Never }\end{array}$ & $\begin{array}{l}\text { The whole clas- } \\
\text { sification scheme } \\
\text { seems kind of racist, } \\
\text { sexist, ableist, etc. } \\
\text { Rarely }\end{array}$ & $\begin{array}{l}\text { The whole clas- } \\
\text { sification scheme } \\
\text { seems kind of racist, } \\
\text { sexist, ableist, etc. } \\
\text { Maybe? }\end{array}$ & $\begin{array}{l}\text { The whole clas- } \\
\text { sification scheme } \\
\text { seems kind of racist, } \\
\text { sexist, ableist, etc. } \\
\text { Sometimes }\end{array}$ & $\begin{array}{l}\text { The whole clas- } \\
\text { sification scheme } \\
\text { seems kind of racist, } \\
\text { sexist, ableist, etc. } \\
\text { Always }\end{array}$ \\
\hline $\begin{array}{l}\text { Inconsistent classification } \\
\text { (for example: some } \\
\text { documentaries are in } \\
\text { subject areas and some } \\
\text { are mixed in with fiction } \\
\text { films) }\end{array}$ & $\begin{array}{l}\text { Inconsistent clas- } \\
\text { sification (for exam- } \\
\text { ple: some documen- } \\
\text { taries are in subject } \\
\text { areas and some are } \\
\text { mixed in with fiction } \\
\text { films) Never }\end{array}$ & $\begin{array}{l}\text { Inconsistent clas- } \\
\text { sification (for exam- } \\
\text { ple: some documen- } \\
\text { taries are in subject } \\
\text { areas and some are } \\
\text { mixed in with fiction } \\
\text { films) Rarely }\end{array}$ & $\begin{array}{l}\text { Inconsistent clas- } \\
\text { sification (for exam- } \\
\text { ple: some documen- } \\
\text { taries are in subject } \\
\text { areas and some are } \\
\text { mixed in with fiction } \\
\text { films) Maybe? }\end{array}$ & $\begin{array}{l}\text { Inconsistent clas- } \\
\text { sification (for exam- } \\
\text { ple: some documen- } \\
\text { taries are in subject } \\
\text { areas and some are } \\
\text { mixed in with fiction } \\
\text { films) Sometimes }\end{array}$ & $\begin{array}{l}\text { Inconsistent clas- } \\
\text { sification (for exam- } \\
\text { ple: some documen- } \\
\text { taries are in subject } \\
\text { areas and some are } \\
\text { mixed in with fiction } \\
\text { films) Always }\end{array}$ \\
\hline Other & O Other Never & O Other Rarely & Other Maybe? & O Other Sometimes & O Other Always \\
\hline
\end{tabular}

23. What additional concerns do you encounter?

24. Is there anything else you would like the researchers or the library community to know? 